\title{
WPS4314
}

Policy Research Working Paper 4314

\section{Labor Regulation and Employment in India's Retail Stores}

\author{
Mohammad Amin
}

The World Bank

Financial and Private Sector Development

Enterprise Analysis Unit

August 2007 
Policy Research Working Paper 4314

\section{Abstract}

A new dataset of 1,948 retail stores in India compiled by the World Bank's Enterprise Surveys shows that 27 percent of the stores report labor regulations as a problem for their business. Using these data we analyze the effect of labor regulation on employment at the store level. We

find that stricter labor regulation has a strong negative effect on employment. Our estimates show that labor reforms are likely to increase employment by 22 percent of the current level for an average store.

This paper — a product of the Financial and Private Sector Development Vice-Presidency, Enterprise Analysis Unit —is part of a larger effort in the department to to better understand the functioning of private sector. Policy Research Working Papers are also posted on the Web at http://econ.worldbank.org. The author may be contacted at mamin@worldbank.org.

The Policy Research Working Paper Series disseminates the findings of work in progress to encourage the exchange of ideas about development issues. An objective of the series is to get the findings out quickly, even if the presentations are less than fully polished. The papers carry the names of the authors and should be cited accordingly. The findings, interpretations, and conclusions expressed in this paper are entirely those of the authors. They do not necessarily represent the views of the International Bank for Reconstruction and Development/World Bank and its affiliated organizations, or those of the Executive Directors of the World Bank or the governments they represent. 


\title{
Labor Regulation and Employment in India's Retail Stores
}

\author{
Mohammad Amin* \\ World Bank
}

Keywords: Labor regulations, India, Employment, Retail JEL: J080, K31, L81, O33, O53

\footnotetext{
*World Bank, Washington DC, 20433. Email: mamin@worldbank.org. Phone: (202)473-1915.
} 


\section{Introduction}

The World Bank conducted a survey of 1,948 retail stores in 16 states (provinces) and 41 cities of India in 2006. The survey shows that $27 \%$ of the respondents find labor regulation to be an obstacle for their business with significant variation in the figure across states. Using this survey, we analyze the effect of labor regulation on employment at the store level. We find that stores hire fewer workers in states with more stringent (pro-worker) labor laws. Our estimates show that labor reforms are likely to increase employment by $22 \%$ of the current level for an average store.

A number of studies have looked at the impact of government policies on economic outcomes. Hall and Jones (1999), Acemoglu et al (2001) and Djankov et al (2002, 2003) show a strong negative effect of bad institutions and heavier regulations on economic performance. Labor regulations in particular have received considerable attention. For example, Botero et al (2004) look at labor regulations in a cross-section of 85 countries and find that rigid regulation of labor is associated with lower labor force participation and higher unemployment. Nickell (1997) attributes higher unemployment in Europe vis-à-vis North America to the rigid labor institutions in the former. Across Indian states, Besley and Burgess (2004) find that rigid labor laws resulted in lower levels of investment, employment, productivity and output in registered manufacturing businesses. Similar findings are reported by Holmes (1988) for manufacturing in the United States and Bertrand and Kramarz (2002) for the retail sector in France.

The present paper contributes to this rich literature in two important ways. First, we focus on a service sector in a developing country. ${ }^{1}$ Existing work on labor regulation

\footnotetext{
${ }^{1}$ Regulation of the labor market is quite rigid in India. For example, the World Bank's Doing Business project ranks India at 112 of 175 countries on the rigidity of employment regulation (World Bank, 2006).
} 
is largely focused on manufacturing sectors despite the fact that services sectors are known to be highly labor intensive, accounting for the majority of jobs across countries. The retail and wholesale sector in India is the second largest employer (after agriculture) providing jobs to $9.4 \%$ of all workers in the country. An adverse effect of labor regulations on employment in the sector can have a significant impact on overall unemployment in the country. Second, existing studies are based on macro data which raises concerns about possible heterogeneity across data points. We find strong evidence of heterogeneity as far as the effect of labor regulation on small vs. large firms is concerned.

The rest of the paper is as follows. In section 2 we describe our data, provide descriptive statistics and discuss the structure of labor laws. In section 3 we outline the estimation strategy. Our empirical results are discussed in section 4. A summary of the main findings is stated in the concluding section.

\section{Data and Main Variables}

We use store level data collected by the World Bank in 2006 (Enterprise survey). ${ }^{2}$ The data are a cross section of 1,948 retail stores spread over 16 states and 41 cities of India. Stores in our sample are a mix of small and large ones. The National Industrial Classification (NIC-1998, Industry Division 52) classifies retailers into those operating through established stores and the rest who usually operate from home. All stores in our sample belong to the former category.

The survey contains information on a variety of store characteristics such as annual sales, employment, availability of infrastructure, access to finance, etc. It also

\footnotetext{
${ }^{2}$ The survey and methodology for data collection are available at www.entersurveys.org.
} 
reports on store's perceptions about various aspects of the business climate like labor regulation, tax rates, restrictions on store-hour operations, etc. We exploit this rich set of information to show that our results are robust to a number of store, city and state characteristics.

\subsection{Dependent variable}

A formal definition of all the variables used in the paper is provided in Table 1. Our main dependent variable is the total number of employees working in a store during the fiscal year 2005-06 (Employment). Total employees include temporary and permanent workers (defined below). The mean value of Employment is 4.7 and the standard deviation equals 24.6. Across states, Employment is highest in the state of Andhra Pradesh (14.1) and lowest in Haryana (.9). In separate regressions, we also use the number of permanent and temporary employees at the store level as dependent variables. Permanent employees are defined as all paid employees that are contracted for a term of one or more fiscal year and/or have a guaranteed renewal of their employment contract and that work 8 or more hours per day. Temporary workers are defined as all paid short-term (less than a fiscal year) employees with no guarantee of renewal of employment contract and that work 8 or more hours per day. We expect the effect of labor regulation to be much stronger (more negative) on permanent than temporary employment since labor regulations are directed mostly towards permanent employees. 


\subsection{Explanatory variables}

Our main explanatory variable is an index of labor regulation (Regs). Not much is known about labor regulations in India's retail sector. These regulations fall under the jurisdiction of the state governments and are contained in the Shops and Establishments Act (SEA). The SEA is a state legislation and contains various laws relating to working conditions of the employees. The main provisions of the Act are as follows:

- Compulsory registration of shop/establishment within thirty days of commencement of work.

- Communications of closure of the establishment within 15 days from the closing of the establishment.

- Regulation of hours of work per day and week.

- Guidelines for spread-over, rest interval, opening and closing hours, closed days, national and religious holidays, overtime work.

- Rules for employment of children, young persons and women.

- Rules for annual leave, maternity leave, sickness and casual leave, etc.

- Rules for employment and termination of service.

- Obligations of employers.

- Obligations of employees.

One concern here is whether labor laws in the SEA are actually enforced. The Enterprise survey provides valuable information on this point. Specifically, in one survey question stores were asked the following: Are labor regulations no obstacle, minor obstacle, moderate obstacle, major obstacle or very severe obstacle to the current operations of the store? Answers to the question were recorded on a 0-4 scale with a higher score implying a greater obstacle. For the full sample, $27 \%$ of the stores reported labor regulations to be a problem (minor or more). For these $27 \%$ of the stores, roughly one third find labor regulations as more than a minor problem. At the high end, 53\% of the stores in West Bengal, 44\% in Rajasthan, 39\% in Maharashtra and 33\% in Delhi report labor regulations 
as a problem. Corresponding figures for labor regulations as more than a minor problem are $25 \%, 12 \%, 10 \%$ and $17 \%$, respectively. Figure 1 shows the percentage of all stores who find labor regulations as obstacles for all the states in our sample. These numbers suggest that a substantial number of retail stores find labor regulations as burdensome, a finding which is confirmed in other surveys too. ${ }^{3}$

Perceptions of stores about the severity of labor regulations discussed above cannot be used directly in the regressions as they are likely to be colored by store characteristics such as size, age, etc. Hence, we define our main measure of labor regulation, the Perception index, as the average value of the reported scores on the labor regulation question above where the average is taken at the state level. Being a group average, the Perception index suffers less from measurement errors and endogeneity problems associated with firm-perceptions (Krueger and Angrist, 2001) although these problems cannot be ruled out completely. For example, if large stores find labor regulations to be more burdensome then part of the variation in the Perception index will simply reflect differences in store-size across states rather than labor laws. We address this problem in two important ways. First, we control for a number of store attributes in our regressions. The intention here is that if store characteristics such as size and age that may affect how stores perceive the severity of labor regulations are controlled for then differences in the underlying labor laws are the only reason why the Perception index would vary across states. Second, we use an alternative measure of labor regulation, the Law Book index, which is an index of labor regulation for the manufacturing sectors in

\footnotetext{
${ }^{3}$ For example, KPMG recently conducted a survey of retail firms in India (KPMG, 2005). This report shows that in the "Fast moving consumer goods" section of retailing about $35 \%$ of the firms reported labor regulations as a significant problem (p. 19). These stores account for $80 \%$ of consumer spending in the country.
} 
India due to Besley and Burgess (2004) ${ }^{4}$. The motivation here is that pro-labor governments are likely to implement labor-friendly laws in both manufacturing and services sectors like retailing. The correlation coefficient between the Perception and the Law Book index is .473. We note that higher values of the labor regulation indices imply stricter (pro-worker) labor regulations.

The Perception index varies between .11 (Haryana, Gujarat) and .81 (West Bengal) with a mean value of .37 and standard deviation of .18 . Figure 2 shows the distribution of the index by state.

Since the Perception index and the Law Book index are defined at the state level, direct reverse causality from Employment (which varies at the store level) to labor regulation is unlikely. However, it is possible that our labor regulation indices could be correlated with other determinants of Employment implying a possible omitted variable bias problem. The issue of measurement errors with the Perception index has already been discussed above. We check for these problems in two ways. First, by directly controlling for a large number of variables at the store, city and state level. Second, we contrast the effect of labor regulations on temporary and permanent employment. While we expect labor regulations to affect employment of these two types of workers differently (as discussed above), there is no reason to expect a similar result for possible covariates of labor regulation.

Additional controls in our main specification include per capita income of the state (Income) $)^{5}$, age of the store (Age) and a measure of store-size which we proxy by the selling/floor area of the shop (Size). Income controls for differences in development

\footnotetext{
${ }^{4}$ We use year 2000 values of the Law Book index which is the latest year for which the index is available.

${ }^{5}$ For Income we use 2003-04 year values at constant 1993-94 prices. This is the latest year for which reliable figures for Income are available.
} 
across states which may affect employment at the store level through the availability of complementary factors (physical and financial infrastructure, etc). Older stores may be more efficient and hence larger in terms of employment due to learning-by-doing. This may bias our results if older stores happen to be disproportionately located across good and bad labor regulation states. Controlling for Age eliminates this source of omitted variable bias.

Floor area of the shop is correlated with a number of store attributes which suggests its use as a proxy for unobservable store characteristics as well. ${ }^{6}$ It also serves as a good proxy for a store's scale of operation since it is highly correlated with annual sales (correlation of .410). The advantage of using floor area over other variables like current sales is that it is largely predetermined and unlikely to suffer from simultaneity problem. In India, new land is acquired primarily for opening a new store rather than expanding (the Size of) an existing one. ${ }^{7}$

The Perception index shows a correlation of -.01 with Size, .13 with Age and .197 with Income. The remaining correlation coefficients are: -.017 (Size and Age), .002 (Size and Income), .003 (Age and Income).

\section{Estimation}

Our base regression is the following

$$
\text { Employment }_{\text {is }}=\beta_{o}+\beta \text { Regs }_{s}+\beta_{1} \text { Size }_{i s}+\beta_{2} \text { Age }_{i s}+\beta_{3} \text { Income }_{s}+u_{i s}
$$

\footnotetext{
${ }^{6}$ For example, access to finance, computer usage, days of inventory maintained by the store and availability of power supply show significant correlation with the floor area of the shop.

${ }^{7}$ In one survey question stores were asked if they had acquired new land in the last three years to expand operations of the current store. Less than $2.9 \%$ of the stores reported doing so.
} 
where $i$ denotes the store and $s$ the state in which the store is located, Employment $t_{i s}$ is total employment in store $i$ in state $s, \operatorname{Reg}_{\mathrm{s}}$ is the index of labor regulation and $u_{i s}$ is the error term. The remaining variables in the equation are as defined above. The coefficient of interest is $\beta$ which we expect to be negative. It captures the impact on employment of a unit increase in the labor regulation index. In all our regressions we use Huber-White robust standard errors clustered on the state. ${ }^{8}$

\subsection{Base regression results}

Results from the estimation of the previous equation using the Perception index (for Regs) are reported in Table 2. Without any controls, labor regulation shows a negative effect on employment but this is not significant at $10 \%$ or less. The estimated coefficient value equals -3.97 with a p-value of .263. Controlling for Age and Income increases the estimated coefficient of the labor regulation index to -5.76 with a p-value of .168 (column 1, Table 2). Income and Age show positive effects on employment but these effects are not statistically significant at $10 \%$ or less. In column 2 of Table 2 we control for Size which shows a positive effect on employment (significant at less than $1 \%$ level). The estimated coefficient of the labor regulation index decreases slightly from -5.76 to -5.33 but it is now significant at less than 5\% level (p-value of .030). Controlling for Size improves the overall fit of the regression dramatically with the $\mathrm{R}^{2}$ rising from .007 (column 1) to .573 (column 2). The improved fit leads to more precise estimates of the various coefficients (lower standard errors) and hence improved significance levels.

\footnotetext{
${ }^{8}$ Our results do not change if we cluster the errors on the city. Clustering lowers the t-statistics of our coefficient of interest.
} 
The final results above (column 2, Table 2) show that the effect of labor regulation on employment is quite large. For example, the state of Madhya Pradesh occupies the median position on our Perception index while Haryana occupies the lowest position. Lowering labor regulations in Madhya Pradesh to the level of Haryana would increase employment for an average store in Madhya Pradesh by about $22 \%$ of the current level.

One concern with the results could be that the negative effect of labor regulation on employment may be restricted to the relatively large stores with smaller stores experiencing no such effect. We do find a substantial reduction in the estimated coefficient of the labor regulation index as we drop the largest 25\% (in terms of Size) of the stores but the coefficient value stabilizes thereafter. More importantly, the estimated coefficient of the labor regulation index remains negative and significant at less than 5\% level even when we drop the relatively large sized stores. In column 3 of Table 2 we report the estimation results with the largest $25 \%$ of the stores dropped from the sample. The coefficient of the labor regulation index equals -.653 here (significant at $5 \%$ level) compared to -5.33 for the full sample (column 2, Table 1). The estimate implies a $7.1 \%$ increase in employment from labor reforms in Madhya Pradesh of the kind mentioned above. As a further check, in column 4 of Table 2 we report the results for the smallest $25 \%$ of the stores. The coefficient of the labor regulation index here equals -.646 (p-value of .007) which is almost the same as we found in the previous specification. Lastly, checking for outliers, we dropped the extreme states (with respect to the Perception index) of West Bengal, Haryana and Gujarat from the sample but this did not change our results above (and elsewhere in the paper) significantly. 


\section{Robustness}

Employment at the store level depends on the marginal productivity of labor vis-à-vis the marginal cost of labor. The list of factors which may affect the marginal benefit/cost of labor can be quite large. In this section we control for a number of factors under the assumption that these factors may affect employment either because they are complimentary or substitutes for labor or because they may affect the overall profitability of business and therefore employment. If these factors happen to be disproportionately distributed across good and bad labor regulation states then they could create an omitted variable bias problem with our estimation of the effect of labor regulation on employment.

Robustness results are reported in Table 3. Stores in our sample are located in the relatively bigger and richer cities of the country which are very different in overall development from the states in which they are located. Hence, it is possible that per capita income of the states (Income) may not adequately capture income differences across cities in our sample. Our first robustness check is motivated to address this problem. Data on income or expenditure at the city level are not available. We use the ratio of female to male population in the city (Sex ratio) as proxy for city-level income. Sex ratio is known to be positively correlated with income and overall development. Controlling for sex ratio lowered the estimated coefficient of the labor regulation index from -5.33 above to -4.16 but it remained significant at less than $5 \%$ level (p-value of .019). Sex ratio showed a positive effect on employment with a coefficient value of 12.2 significant at less than $10 \%$ level (p-value of .059). There was no significant change in the results for the remaining controls. 
Next, we control for total adult population the city (Population). The variable captures differences in labor availability across cities and also income differences since larger cities are known to be richer, endowed with better infrastructure, etc. In our sample, the cities of Mumbai, New Delhi, Chennai, Bangalore, Kolkatta and Hyderabad show highest values of Population. These cities are known to be the richest cities in the country and they are also the main beneficiaries of the ongoing retail boom. Regression results with Population as an additional control are reported in column 1 of Table 3. As expected, Population has a positive effect on employment but this effect is not too significant here (p-value of .174). The estimated coefficient of the labor regulation index equals -5.94 significant at less than $5 \%$ compared to -4.16 in the previous specification. There is not much change in the results for the remaining variables.

In the Enterprise survey, stores reported irregular power supply and access to finance as the two biggest problems they faced in running their business. These problems could limit the overall profitability and size of business and also the marginal productivity of labor, lowering employment. This could bias our main results if power supply and access to finance differ systematically by labor laws. We check for this possibility using the following controls taken from the survey: duration of power outage faced by a store per day on an average (Outage), a dummy variable equal to 1 if a store uses a generator and 0 otherwise (Generator), a dummy equal to 1 if a store has checking/savings account and 0 otherwise (Checking), and a dummy equal to 1 if a store reported "no need to borrow externally" in the last fiscal year and 0 otherwise (Liquid). Regression results with these additional controls are reported in column 2 of Table 3 . The estimated coefficient of the labor regulation index here is higher in magnitude than in the 
previous specification equaling -6.51 and significant at less than $5 \%$ level. Checking and Generator show positive effects on employment significant at less than $1 \%$ level. The estimated coefficients of Outage and Liquid have their expected signs but these are not significant at $10 \%$ or less. There is no noticeable change in the estimated effects of the remaining variables except that Population now shows a statistically significant positive effect on employment (at less than 5\% level).

One concern with the results above could be that states with more stringent labor laws may have higher wages for reasons which have nothing to do with labor laws. For example, differences in the skill and education levels of the labor force may lead to wage differentials across states correlated with labor laws. If this is indeed the case then our results for the effect of labor regulation on employment could suffer from an identification problem. To some extent we are insulated from this problem because our controls for Income, Sex ratio and Population are likely to pick up some of the difference in the opportunity cost of labor across states and cities. For additional robustness, we control for adult literacy rate of the states (Literacy) which we expect to be positively correlated with the opportunity cost of labor. Regression results are reported in column 3 of Table 3. These results are along expected lines. They show that Literacy has a negative effect on employment which is significant at less than $5 \%$ level. The estimated coefficient of the labor regulation index does decline from -6.51 in the previous specification to 5.41 but remains significant at less than $5 \%$ level (p-value of .035). The only other significant change here is in the estimated coefficient of Income which is now positive and significant at less than $10 \%$ level. The significant and positive effect of Income here is not surprising. Better infrastructure, etc., associated with higher income should have a 
positive effect on employment but at the same the cost of labor is also likely to be higher in the richer states. The latter effect puts a downward pressure on the estimated coefficient of Income. The control for literacy as a proxy for the opportunity cost of labor filters out this downward pressure yielding a more positive effect of Income on employment. The robustness of our main result with respect to literacy rate raises our confidence that our measure of labor regulation is not picking up differences in skill level or opportunity cost of labor for reasons other than labor regulation. ${ }^{9}$

Our next control is a dummy variable equal to 1 if a store uses a computer for running its business and 0 otherwise (Computers).$^{10} 19 \%$ of the stores in our sample use computers with a high of $40 \%$ in the state of Kerala. The impact of computer usage (and modern technology in general) on employment is hotly debated in the literature. One view is that computers substitute for labor, especially in routine jobs which can be easily automated (Bresnahan, 1997). The opposite view is that computers complement labor by helping them perform more complicated tasks (Autor, Katz and Krueger, 1998). Controlling for computer usage did not change our results much. The estimated coefficient of the labor regulation index remained significant at less than 5\% level and rose in magnitude from -5.41 above to -5.61 (p-value of .015 ). The coefficient of Computers equaled 6.23 significant at less than $1 \%$ level. There was no significant change in the estimated effects of the remaining controls.

\footnotetext{
${ }^{9}$ However, some caution is necessary in interpreting the effect of literacy we found above for the following reasons. First, the correlation coefficient between Income and Literacy is quite high (.750) and the estimated coefficient of Literacy is significant at only close to $10 \%$ level if we do not control for Income in the previous specification. Second, we experimented with using literacy rate at the city level. While the results for the effect of labor regulation on employment did not change much, the negative effect of literacy on employment was significant at only close to $10 \%$ level. The reason for this could be that city-level literacy rate picks up income differences across cities biasing its estimated coefficient towards zero.

${ }^{10}$ Data on hours of computer usage or number of workers using computers are not available.
} 
It is possible that labor regulation could be spuriously picking up the effect of the broader investment climate. In one survey question, stores were asked whether tax rates, tax administration, corruption, obtaining licenses and permits, restrictions on store-hour operations, access to land (land laws, land availability, etc) and regulations on pricing and mark-ups are an obstacle for their business. Responses for each of these obstacles were recorded separately on a $0-4$ scale with a higher value on the scale implying a greater obstacle. ${ }^{11}$ As for the Perception index, we first took state level averages of the reported scores for each of these obstacles to arrive at various sub-indices of business regulations. Next we took the simple average of the sub-indices to arrive at the overall measure of the regulatory environment (Business Regulations). In column 4 of Table 3 we report regression results controlling for Business Regulations. These results are roughly similar to what we found in the previous specification and Business Regulations does not show any significant effect on employment. ${ }^{12}$

Next, we check whether the negative effect of labor regulation on employment holds for the relatively smaller stores or not. As we found for the main specification, excluding the largest $25 \%$ of the stores lowers the estimated coefficient of the labor regulation index from -6.84 above to -1.38 significant at less than $1 \%$ level. For the smallest $25 \%$ of the sample, the corresponding coefficient value equals -1.84 significant at less than 5\% level (p-value of .018).

We performed a number of additional robustness checks and found that our main results discussed above did not change much. We discuss these checks briefly here. First,

\footnotetext{
${ }^{11}$ The 0-4 scale here is defined as follows: No obstacle (0), Minor obstacle (1), Moderate obstacle (2), Major obstacle (3) and Very severe obstacle (4).

${ }^{12}$ We experimented with a few additional controls for the overall investment climate and also controlled for the individual sub-indices of Business Regulations. However, this did not change our results significantly.
} 
starting with the specification in column 4 of Table 3, we controlled for the level of formal and informal competition faced the stores in our sample. ${ }^{13}$ Second, we controlled for the remaining two finance related variables reported in the survey which are dummy specifications for whether or not a store has a line of credit and overdraft facility. Third, we controlled for the number of days of inventory maintained by the store, a dummy variable equal to 1 if a store has a female principal owner and 0 otherwise, a dummy variable equal to 1 if a store is part of a larger chain and 0 otherwise, a dummy variable equal to 1 if a store reported experiencing theft during the year 2005-06 and 0 otherwise, and the proportion of a store's annual sales in 2005-06 that were never paid for. Fourth, we controlled for the percentage of stores' senior management's time that is spent in dealing with business regulations. Fifth, we added a dummy variable equal to 1 if a store is located in a metropolitan city (Mumbai, Delhi, Kolkatta, Bnagalore, Chennai and Hyderabad) and 0 otherwise, a set of two dummy variables indicating whether a store is located in a leading or a lagging state (omitted category is the set of middle-income states) $)^{14}$, and square of Size $\left(\right.$ Size $\left.^{2}\right)$ to capture any possible non-linear effect of store-size on employment. With all these controls added, the estimated coefficient of the labor regulation index equaled -6.08 significant at less than 5\% level (p-value of .039).

\footnotetext{
${ }^{13}$ In one survey question stores were asked how important was the influence of formal and informal (people selling from pavements, etc) competitors over the prices of their products. Responses were recorded on a 1-4 scale, for each form of competition separately, with a higher value on the scale implying more competition. Our competition measures equal the average score at the city level for each form of competition. Although not important for our results, averaging was done to filter out store specific attributes from store-level responses.

${ }^{14}$ The definition of leading, lagging and middle states is taken from Kochar et al (2006). The authors look at a number of state level development indicators including the quality of physical infrastructure, financial development, penetration of mass media, literacy rates and historical land tenure systems. Based on these indicators they group states into the three categories. Leading states are: Delhi, Gujarat, Karnataka, Kerala, Maharashtra and Punjab. Lagging states include Bihar, Jharkhand, Madhya Pradesh, Orissa and Uttar Pradesh. The remaining states belong to the intermediate middle group.
} 


\subsection{Law Book index}

Estimation results using the Law Book index as the measure of labor regulation are reported in Table 4. Irrespective of the controls, the coefficient of the Law Book index is negative. It is significant at less than $10 \%$ level without any controls (column 1, Table 4) and at less than 5\% level once we control for Age and Income (column 2, Table 4). For the base specification, the estimated coefficient is significant at less than $1 \%$ level and equals -1.07 (column 3, Table 4). Adding the various controls discussed above lowers the coefficient value slightly to -.979 significant at less than $1 \%$ level (column 4 , Table 4).

As for the Perception index, the estimated coefficient of the Law Book index declines sharply but remains significant at less than 5\% level when we drop the largest $25 \%$ of the stores from the sample. For example, for the specification in column 4 of Table 4, the estimated coefficient of the Law Book index drops from -.907 for the full sample to -.162 significant at less than $1 \%$ level when we drop the largest $25 \%$ of the stores. The corresponding value for the sample of the smallest $25 \%$ of the stores equals -.177 (p-value of .005).

\subsection{Temporary versus permanent employment}

We argued above that labor regulations are directed mostly towards permanent workers. One implication of this is that the negative effect of labor regulation should be stronger for permanent than temporary employment. Our results confirm this thinking. Columns 1 and 2 of Table 5 report the regression results with permanent and temporary employment as the dependent variables, respectively. In these two columns we use the Perception 
index and our main (baseline) controls. Corresponding results using the Law Book index are reported in columns 3 and 4 of the same table.

These results show that the effect of labor regulation on permanent employment is roughly similar to what we found above for total employment. For example, a unit increase in the Perception index changes permanent employment by -4.76 (p-value of .024 , column 1, Table 5). The corresponding figures with total and temporary employment as dependent variables are -5.33 (p-value of .030; column 2, Table 3) and -.734 (p-value of .352; column 2, Table 5), respectively. Adding all the controls used for the robustness analysis (listed in column 4, Table 3 ) yields an estimated coefficient value of -6.48 (p-value of .033) for the Perception index with permanent employment as the dependent variable. The corresponding values with total and temporary employment as dependent variables are -6.84 (p-value of .040) and -.360 (p-value of .585), respectively.

Regression results using the Law Book index show a similar pattern (columns 3 and 4 , Table 5). The only difference here is the negative effect of the index on temporary employment in the main specification is significant at less than $10 \%$ level (column 4 , Table 5) although it is much lower (less negative) in value than for permanent employment (column 3, Table 5). However, even this weak negative effect becomes insignificant (at $10 \%$ or less) as we add some of the controls used in the robustness checks (listed in column 4 of Table 3 ). ${ }^{15}$

\footnotetext{
${ }^{15}$ Using the Law Book index and controlling for all the variables listed in column 4 of Table 3 (except for the Perception index) yielded an estimated coefficient value of -.163 with a p-value of .127 for the Law $B o o k$ index with temporary employment as the dependent variable. Corresponding values with permanent and total employment as dependent variables are -.816 ( $\mathrm{p}$-value of .013) and -.979 ( $\mathrm{p}$-value of .005), respectively.
} 


\section{Conclusion}

A number of studies have shown that burdensome labor regulations can hinder job creation. These studies are largely confined to the manufacturing sectors and use macro data. The present paper finds similar evidence for a services sector (retailing) using micro data. Our results show that labor regulation in India's retail sector is detrimental to job creation and that labor reforms could increase employment in the sector by as much as $22 \%$ for an average store. This is a large effect when we take into account the fact that the retail sector in India is the second largest employer providing jobs to $9.4 \%$ of all workers. Our results also show that the harmful effect of burdensome labor laws on employment is particularly strong for the large retailers. This is important because the retail sector in India is rapidly moving towards large-sized retailing. 


\section{References}

Acemoglu, Daron, Simon Johnson and James A. Robinson (2001), "The Colonial Origins of Comparative Development: An Empirical Investigation," American Economic Review, XCI, 1369-1401.

Amin, M (2007), “Competition and Labor Productivity in India's Retail Stores," mimeograph.

Autor, D.H., L.F. Katz and A.B. Krueger (1998), "Computing Inequality: Have Computers Changed the Labor Market?" Quarterly Journal of Economics, 113, pp. 1169-1213.

Banerjee, A and L. Iyer (2005), "History, Institutions and Economic Performance: The Legacy of Colonial Land Tenure Systems in India," American Economic Review, 95(4), 1190-1213.

Bertrand, Marianne and Francis Kramarz (2002), "Does Entry Regulation Hinder Job Creation? Evidence from the French Retail Industry," Quarterly Journal of Economics, CXVII, 1369-1413.

Besley, Timothy and Robin Burgess (2004), "Can Labor Regulation Hinder Economic Performance? Evidence from India," Quarterly Journal of Economics, February 2004, 91-134.

Botero, Juan, Simeon Djankov, Rafael La Porta, Florencio Lopez-de-Silanes and Andrei Shleifer (2004), "The Regulation of Labor," Quarterly Journal of Economics, November, 118: 1339-1382.

Bresnahan, Timothy, F. (1997), "Computerization and Wage Dispersion: An Analytical Reinterpretation," unpublished paper, Stanford University.

Card, David, Francis Kramarz and Thomas Lemieux (1999), "Changes in Relative Structure of Wages and Employment: A Comparison of the United States, Canada and France," Canadian Journal of Economics, 32(4), 843-877.

Djankov, Simeon, Rafael La Porta, Florencio Lopez-de-Silanes and Andrei Shleifer (2002), "The Regulation of Entry," Quarterly Journal of Economics, 117: 1-37.

Djankov, Simeon, Edward Glaeser, Rafael La Porta, Florencio Lopez-de-Silanes and Andrei Shleifer (2003), "The New Comparative Economics," Journal of Comparative Economics, December.

Hall, Robert E. and Charles Jones (1999), "Why Do Some Countries Produce So Much More Output per Worker than Others?" Quarterly Journal of Economics, 114, 83-116.

Holmes, Thomas. (1998), "The Effect of State Policies on the Location of Manufacturing: Evidence from State Borders," Journal of Political Economy, CVI, 667-705.

Kochar, Kalpana. Utsav Kumar, Raghuram Rajan, Arvind Subramanian and Ioannis Tokatlidis (2006), "India's Pattern of Development: What happened, what follows?" Journal of Monetary Economics, 53(5), pp. 981-1019.

KPMG (2005), Consumer Markets in India - The Next Big Thing?, KPMG International. 
Krueger, A.B and J. Angrist (2001), "Instrumental Variables and the Search for Identification: From Supply and Demand to Natural Experiments?" Journal of Economic Perspectives, 15, pp. 69-85.

Nickell, Stephen (1997), "Unemployment and Labor Market Rigidities: Europe versus North America," Journal of Economic Perspectives, XI, 55-74.

World Bank (2006), Doing Business 2007: How to Reform, Washington DC. 


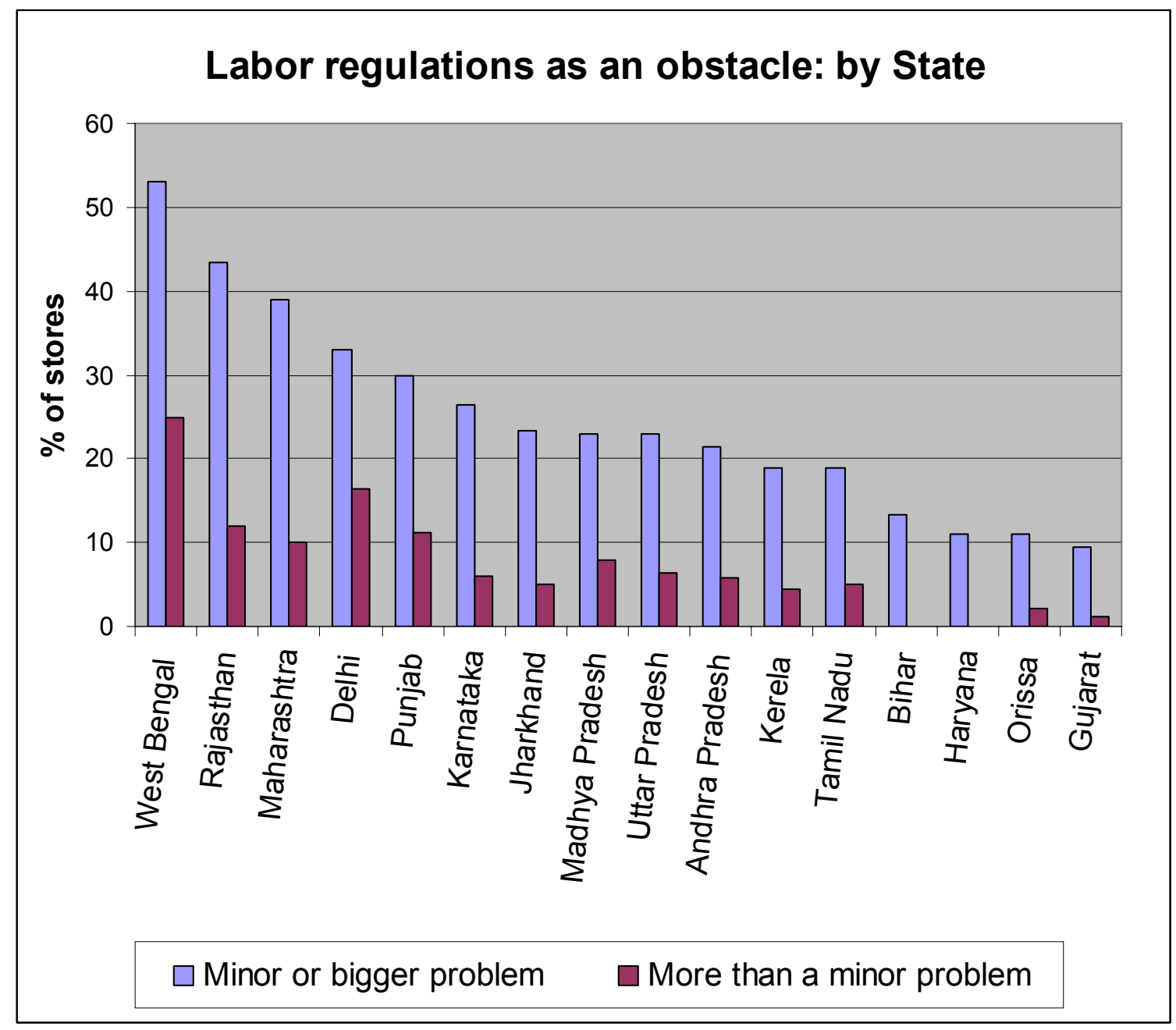

Figure 1 


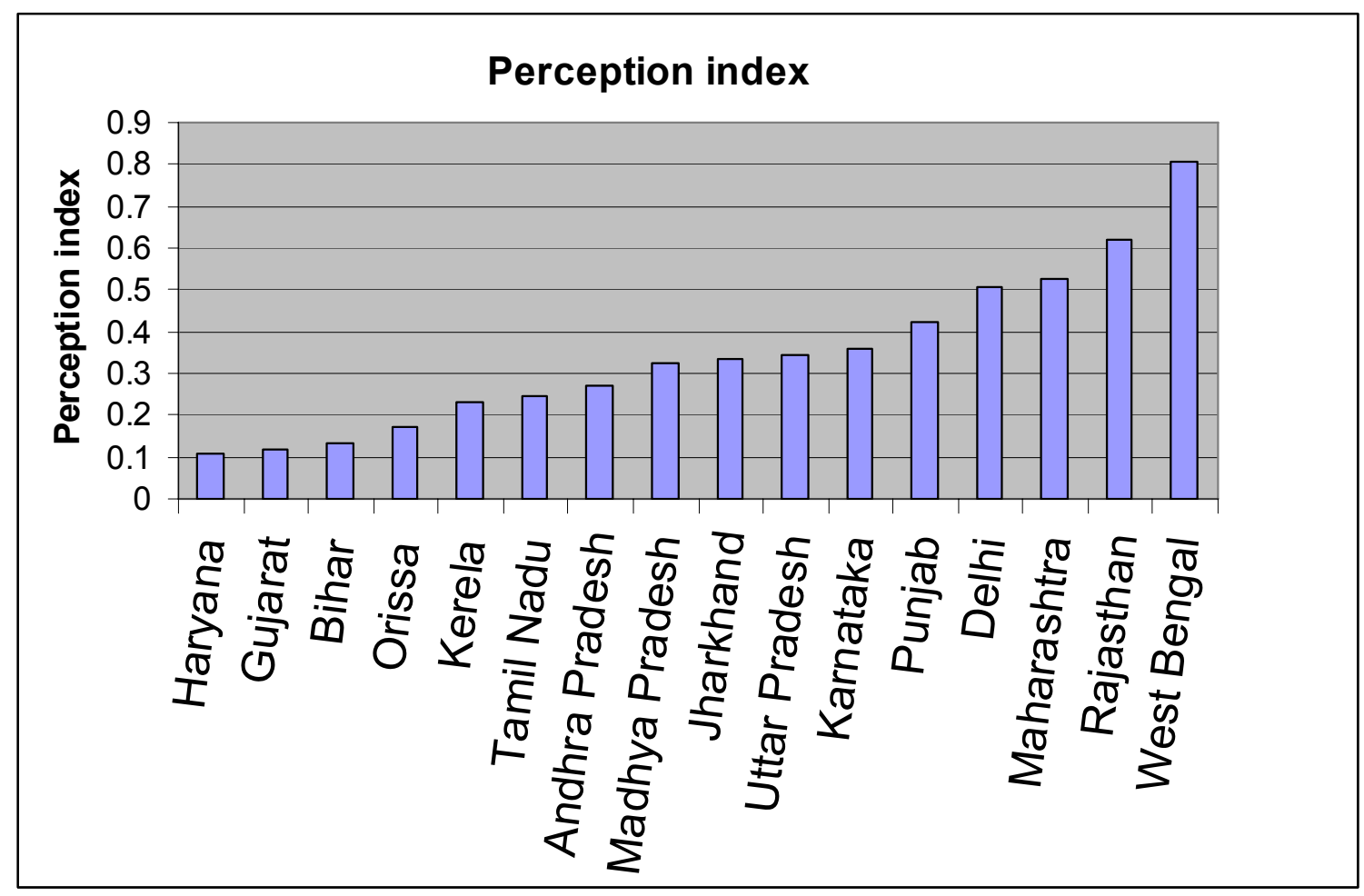

Figure 2 


\section{Table 1: Description of Main Variables}

\begin{tabular}{l|l}
\hline Variable & Description \\
"Last fiscal year" below means fiscal year 2005-06. \\
\begin{tabular}{c|l} 
Employment & $\begin{array}{l}\text { Total number of workers working in the store in the } \\
\text { last fiscal year as reported by the respondents in the } \\
\text { Enterprise Survey. } \\
\text { Source: World Bank Enterprise Surveys } \\
\text { (www.enterprisesurveys.org) }\end{array}$ \\
Labor regulation indices (Regs) & $\begin{array}{l}\text { Total selling area of the store measured in square feet } \\
\text { (millions) }\end{array}$ \\
Perception index & $\begin{array}{l}\text { Source: World Bank Enterprise Surveys } \\
\text { (www.enterprisesurveys.org) }\end{array}$ \\
State level average value of the scores reported in the \\
Enterprise Survey for the following question: "Are \\
labor regulations No Obstacle, a Minor Obstacle, a \\
Major Obstacle, or a Very Severe Obstacle to the \\
current operations of this store?" The scores for these \\
choices are from 0,1,2,3 and 4, respectively. Higher \\
values of the index imply more pro-worker laws. \\
Source: World Bank Enterprise Surveys \\
(www.enterprisesurveys.org) \\
An index of labor laws in formal manufacturing in \\
India due to Besley and Burgess (2004). We use year \\
2000 values of the index which is the latest available. \\
The index is not available for the state of Delhi. \\
2006 minus the year shop was established. \\
Source: World Bank Enterprise Surveys \\
(www.enterprisesurveys.org) \\
Per capita income of the states in 2003-04 at 1993-94 \\
constant prices. \\
Source: Reserve Bank of India, based on CSO data.
\end{tabular} \\
\hline Income
\end{tabular}

\section{Description of Other Variables}

Variable
Permanent employment

\section{Description}

Number of permanent employees at the end of last fiscal year. Permanent employees are defined as all paid employees that are contracted for a term of one or more fiscal years and/or have a guaranteed renewal of their employment contract and that work 8 or more hours per day.

Source: World Bank Enterprise Surveys

(www.enterprisesurveys.org) 
Temporary employment

Outage

Generator

Checking

Liquid

Sex ratio

Literacy

Population

Computers

Business Regulations
Number of temporary employees in the last fiscal year. Temporary workers are defined as all paid short-term (i.e. for less than a fiscal year) employees with no guarantee of renewal of contract employment and that work 8 or more hours per day.

Source: World Bank Enterprise Surveys

(www.enterprisesurveys.org)

Total number of hours of power failure faced by a store per day in a typical month.

Source: World Bank Enterprise Surveys

(www.enterprisesurveys.org)

A dummy variable equal to 1 if a store owns or shares a generator/inverter and 0 otherwise.

Source: World Bank Enterprise Surveys

(www.enterprisesurveys.org)

A dummy variable which equals 1 if a store has a checking or savings account and 0 otherwise.

Source: World Bank Enterprise Surveys

(www.enterprisesurveys.org)

A dummy variable equal to 1 if a store reports "no need to borrow from external sources" during the last fiscal year and 0 otherwise.

Source: World Bank Enterprise Surveys

(www.enterprisesurveys.org)

Ratio of females to males in the city in 2001.

Source: Census of India, 2001.

Percentage of adults in the state who are literate in 2001.

Source: Census of India, 2001.

Total adult population of the city in 2001 (in millions).

Source: Census of India, 2001.

A dummy variable equal to 1 if a store uses a computer for its business and 0 otherwise.

Source: World Bank Enterprise Surveys

(www.enterprisesurveys.org)

The index was constructed in two steps. In the first step we constructed sub-indices which are state level averages of scores reported by stores on the following questions: Is/Are the following No obstacle (0), Minor obstacle (1), Moderate obstacle (2), Major obstacle (3) or Very severe obstacle (4) to the current operations and growth of the store? Tax rates, Tax administration, Corruption, Access to Land, Business licensing and permits, Regulations on hours of operation, Regulations on pricing \& mark-ups.

In the second step we took the simple average over the various sub-indices for each state.

Source: World Bank Enterprise Surveys

(www.enterprisesurveys.org) 
Table 2: The Effect of Labor Regulation on Employment

\begin{tabular}{|c|c|c|c|c|}
\hline & $(1)$ & $(2)$ & (3) & (4) \\
\hline $\begin{array}{l}\text { Regs } \\
\text { (Perception index) }\end{array}$ & $\begin{array}{l}-5.76 \\
(.168)\end{array}$ & $\begin{array}{l}-5.33^{* *} \\
(.030)\end{array}$ & $\begin{array}{l}-.653^{* *} \\
(.050)\end{array}$ & $\begin{array}{l}-.646^{* * *} \\
(.007)\end{array}$ \\
\hline Age & $\begin{array}{l}.152 \\
(.154)\end{array}$ & $\begin{array}{l}.177 \\
(.131)\end{array}$ & $\begin{array}{c}.012^{*} \\
(.089)\end{array}$ & $\begin{array}{l}.011^{* *} \\
(.083)\end{array}$ \\
\hline Income & $\begin{array}{l}.031 \\
(.632)\end{array}$ & $\begin{array}{c}.025 \\
(.328)\end{array}$ & $\begin{array}{l}.011^{* *} \\
(.032)\end{array}$ & $\begin{array}{c}.003 \\
(.414)\end{array}$ \\
\hline Size & & $\begin{array}{l}5.21^{* * *} \\
(.000)\end{array}$ & $\begin{array}{l}7.18^{* * *} \\
(.000)\end{array}$ & $\begin{array}{l}7.88^{* * *} \\
(.001)\end{array}$ \\
\hline Constant & $\begin{array}{l}4.95^{*} \\
(.059)\end{array}$ & $\begin{array}{c}1.45 \\
(.358)\end{array}$ & $\begin{array}{l}.986^{* * *} \\
(.000)\end{array}$ & $\begin{array}{l}1.06^{* * *} \\
(.000)\end{array}$ \\
\hline $\mathrm{R}^{2}$ & .007 & .573 & .068 & .050 \\
\hline Sample Size & 1948 & 1938 & 1455 & 444 \\
\hline \multicolumn{5}{|c|}{$\begin{array}{l}\text { p-values in brackets. All regressions use Huber-White correction for } \\
\text { heteroskedasticity with standard errors clustered on the state. } \\
\text { Significance levels are denoted by }{ }^{* * *}(1 \% \text { or less }),{ }^{* *}(5 \% \text { or less }) \\
\text { and }{ }^{*}(10 \% \text { or less). Results in columns } 1 \text { and } 2 \text { are based on the full } \\
\text { sample of } 1948 \text { stores with } 10 \text { observations dropped in column } 2 \\
\text { due to missing data on Size. In column } 3 \text { the largest } 25 \% \text { of the } \\
\text { stores (in terms of Size) are excluded from the sample. In column } 4 \\
\text { the sample is restricted to the smallest } 25 \% \text { of the stores (in terms of } \\
\text { Size). }\end{array}$} \\
\hline
\end{tabular}


Table 3: The Effect of Labor Regulation on Employment

\begin{tabular}{|c|c|c|c|c|}
\hline & (1) & (2) & (3) & (4) \\
\hline Regs (Perception & $-5.94^{* *}$ & $-6.51^{* *}$ & $-5.41^{* *}$ & $-6.84^{* *}$ \\
\hline index) & $(.027)$ & $(.012)$ & $(.035)$ & $(.040)$ \\
\hline \multirow[t]{2}{*}{ Age } & .180 & .164 & .162 & .170 \\
\hline & $(.134)$ & $(.168)$ & $(.174)$ & $(.152)$ \\
\hline \multirow[t]{2}{*}{ Income } & -.007 & -.017 & $.105^{*}$ & $.097^{* * *}$ \\
\hline & $(.836)$ & $(.604)$ & $(.077)$ & $(.044)$ \\
\hline \multirow[t]{2}{*}{ Size } & $5.19^{* * *}$ & $5.11^{* * *}$ & $5.11^{* * *}$ & $5.00^{* * *}$ \\
\hline & $(.000)$ & $(.001)$ & $(.000)$ & $(.001)$ \\
\hline \multirow[t]{2}{*}{ Sex ratio } & $15.5^{* *}$ & $16.2^{* * *}$ & $22.7^{* * * *}$ & $20.6^{* * *}$ \\
\hline & $(.037)$ & $(.049)$ & $(.005)$ & $(.017)$ \\
\hline \multirow[t]{2}{*}{ Population } & .992 & $1.34^{*}$ & $1.31^{*}$ & $1.30^{*}$ \\
\hline & $(.174)$ & $(.074)$ & $(.081)$ & $(.081)$ \\
\hline \multirow[t]{2}{*}{ Outage } & & -.036 & -.071 & -.032 \\
\hline & & $(.669)$ & $(.392)$ & $(.708)$ \\
\hline \multirow[t]{2}{*}{ Generator } & & $3.45^{* * * *}$ & $3.42^{* * * *}$ & $1.67^{* *}$ \\
\hline & & $(.001)$ & $(.001)$ & $(.020)$ \\
\hline \multirow[t]{2}{*}{ Checking } & & $1.26^{* * *}$ & $1.42^{* * * *}$ & $.664^{*}$ \\
\hline & & $(.001)$ & $(.002)$ & $(.100)$ \\
\hline \multirow[t]{2}{*}{ Liquid } & & .832 & 1.01 & .955 \\
\hline & & $(.327)$ & $(.270)$ & $(.318)$ \\
\hline \multirow[t]{2}{*}{ Literacy } & & & $-.170^{* *}$ & $-.170^{* *}$ \\
\hline & & & $(.027)$ & $(.011)$ \\
\hline \multirow[t]{2}{*}{ Computers } & & & & $6.31^{* *}$ \\
\hline & & & & $(.000)$ \\
\hline \multirow{2}{*}{$\begin{array}{l}\text { Business } \\
\text { regulations }\end{array}$} & & & & 1.39 \\
\hline & & & & $(.331)$ \\
\hline \multirow[t]{2}{*}{ Constant } & $-25.6^{*}$ & $-32.7^{* *}$ & $-29.8^{* *}$ & $-28.5^{*}$ \\
\hline & $(.079)$ & $(.036)$ & $(.042)$ & $(.073)$ \\
\hline $\mathrm{R}^{2}$ & .575 & .582 & .583 & .590 \\
\hline Sample Size & 1938 & 1926 & 1926 & 1926 \\
\hline \multicolumn{5}{|c|}{$\begin{array}{l}\text { p-values in brackets. All standard errors are Huber-White robust and clustered o } \\
\text { the state. Significance levels are denoted by: }{ }^{* * *}(1 \% \text { or less }),{ }^{* *}(5 \% \text { or less }) \text { and } \\
(10 \% \text { or less }) .\end{array}$} \\
\hline
\end{tabular}


Table 4: The Effect of Labor Regulation on Employment

\begin{tabular}{|c|c|c|c|c|}
\hline & (1) & (2) & (3) & (4) \\
\hline Regs (Law Book & $-1.09^{*}$ & $-1.33^{* *}$ & $-1.07^{* * *}$ & $-.979^{* * *}$ \\
\hline index) & $(.075)$ & $(.030)$ & $(.001)$ & $(.005)$ \\
\hline \multirow[t]{2}{*}{ Age } & & .159 & .188 & .183 \\
\hline & & $(.166)$ & $(.133)$ & $(.149)$ \\
\hline \multirow[t]{2}{*}{ Income } & & $.172^{*}$ & $.080^{* *}$ & $.169^{* * *}$ \\
\hline & & $(.062)$ & $(.036)$ & $(.005)$ \\
\hline \multirow[t]{2}{*}{ Size } & & & $5.20^{* * *}$ & $4.99^{* * *}$ \\
\hline & & & $(.000)$ & $(.000)$ \\
\hline \multirow[t]{2}{*}{ Sex ratio } & & & & 4.62 \\
\hline & & & & $(.610)$ \\
\hline \multirow{2}{*}{ Population } & & & & $1.15^{*}$ \\
\hline & & & & $(.064)$ \\
\hline \multirow[t]{2}{*}{ Outage } & & & & -.018 \\
\hline & & & & $(.847)$ \\
\hline \multirow[t]{2}{*}{ Generator } & & & & $1.55^{* *}$ \\
\hline & & & & $(.026)$ \\
\hline \multirow[t]{2}{*}{ Checking } & & & & .642 \\
\hline & & & & $(.116)$ \\
\hline \multirow[t]{2}{*}{ Liquid } & & & & .791 \\
\hline & & & & $(.440)$ \\
\hline Literacy & & & & $-.163^{* * *}$ \\
\hline \multirow{2}{*}{ Computers } & & & & $\begin{array}{l}(.007) \\
6.43^{* * *}\end{array}$ \\
\hline & & & & $(.000)$ \\
\hline \multirow{2}{*}{$\begin{array}{l}\text { Business } \\
\text { regulations }\end{array}$} & & & & -.477 \\
\hline & & & & $(.677)$ \\
\hline \multirow[t]{2}{*}{ Constant } & $6.11^{* * *}$ & .208 & -1.55 & 14.7 \\
\hline & $(.000)$ & $(.921)$ & $(.423)$ & $(.206)$ \\
\hline $\mathrm{R}^{2}$ & .005 & .014 & .578 & .594 \\
\hline Sample Size & 1838 & 1838 & 1828 & 1817 \\
\hline \multicolumn{5}{|c|}{$\begin{array}{l}\text { p-values in brackets. All standard errors are Huber-White robust and clustered on } \\
\text { the state. Significance levels are denoted by: }{ }_{* * *}(1 \% \text { or less }),{ }^{* *}(5 \% \text { or less }) \text { and } \\
(10 \% \text { or less }) . \text { Law Book index is not available for the state of Delhi. }\end{array}$} \\
\hline
\end{tabular}


Table 5: Temporary versus permanent employment

\begin{tabular}{|c|c|c|c|c|}
\hline & \multicolumn{2}{|c|}{ Perception index } & \multicolumn{2}{|c|}{ Law Book index } \\
\hline & $\begin{array}{c}\text { Permanent } \\
\text { employment }\end{array}$ & $\begin{array}{c}\text { Temporary } \\
\text { employment }\end{array}$ & $\begin{array}{l}\text { Permanent } \\
\text { employment }\end{array}$ & $\begin{array}{l}\text { Temporary } \\
\text { employment }\end{array}$ \\
\hline & (1) & (2) & (3) & (4) \\
\hline \multirow[t]{2}{*}{ Regs } & $-4.60^{* *}$ & -.734 & $-.865^{* *}$ & $-.202^{*}$ \\
\hline & $(.024)$ & $(.352)$ & $(.007)$ & $(.061)$ \\
\hline \multirow[t]{2}{*}{ Age } & .136 & $.041^{* * *}$ & .143 & $.044^{* *}$ \\
\hline & $(.211)$ & $(.037)$ & $(.218)$ & $(.029)$ \\
\hline \multirow[t]{2}{*}{ Income } & .019 & .006 & $.059^{*}$ & .020 \\
\hline & $(.371)$ & $(.429)$ & $(.092)$ & $(.155)$ \\
\hline \multirow[t]{2}{*}{ Size } & $4.22^{* * *}$ & $.986^{* * *}$ & $4.21^{* * *}$ & $.984^{* * *}$ \\
\hline & $(.001)$ & $(.003)$ & $(.001)$ & $(.004)$ \\
\hline \multirow[t]{2}{*}{ Constant } & .600 & -.146 & -1.82 & $-.724^{*}$ \\
\hline & $(.651)$ & $(.623)$ & $(.305)$ & $(.089)$ \\
\hline $\mathrm{R}^{2}$ & .515 & .407 & .519 & .413 \\
\hline Sample Size & 1938 & 1938 & 1828 & 1828 \\
\hline \multicolumn{5}{|c|}{$\begin{array}{l}\text { p-values in brackets. All regressions use Huber-White correction for } \\
\text { heteroskedasticity with standard errors clustered on the state. Significance } \\
\text { levels are denoted by }{ }^{* * *} \text { ( } 1 \% \text { or less), }{ }^{* *}(5 \% \text { or less }) \text { and }{ }^{*}(10 \% \text { or less). All } \\
\text { regressions are based on the full sample. Sample size in columns (3) and (4) } \\
\text { is smaller because the Law Book index is not available for the state of Delhi. }\end{array}$} \\
\hline
\end{tabular}

